\title{
nature
}

\section{Grounds for hope on AIDS in Africa}

Despite the pervasive tension between AIDS researchers and the South African government, last week's international AIDS conference in Durban was successful on several fronts.

$\mathrm{D}$ oubts have been expressed in the past, in Nature and elsewhere, about the value of huge, international jamborees of several thousand AIDS researchers and activists, government officials, drug company executives and news reporters. But the 13 th International AIDS Conference, which ended last week in Durban, can already claim a number of significant achievements.

One of these has been the way it has focused global attention on the urgent need to make treatment available to people with HIV/AIDS where the epidemic is most serious — in sub-Saharan Africa. Even members of the US Congress normally contemptuous of the concept of foreign aid appear to have discovered the moral imperative of addressing this problem aggressively. Last week the House of Representatives unexpectedly voted for modest additional resources for dealing with the problem.

A second achievement was the meeting's showcasing of several areas of progress in AIDS research that provide hope in the face of the horrifying spread of the epidemic. Researchers reported, for example, that antiretroviral treatments can help to prevent the transmission of HIV from mother to child, even if breastfeeding continues. And preliminary work indicates that the combination therapies now routinely used in the developed world can treat HIV effectively even in poor countries with little health-care infrastructure.

The meeting also brought extra pressure to bear on South African president Thabo Mbeki and his government to address the epidemic with appropriate means and urgency.

The effectiveness of antiretroviral drugs in preventing mother-tochild transmission was a focal point of the conference. Independent studies have shown that short courses of these drugs are both relatively safe and effective. The possibility of transmission through breastfeeding after treatment remains a focus of research, as does drug resistance. But early indications are that, even where breastfeeding cannot be avoided, transmission of HIV from mother to child is significantly reduced, particularly with early weaning. The meeting also heard evidence of the efficacy of the antiretroviral drug nevirapine, which is cheaper and simpler to administer than AZT.

None of this answers the critical question of how developing countries can afford treatment. But some answers may be forthcoming - for example, last month's offer by five drug companies to provide AIDS drugs to developing countries at reduced prices (see Nature 405,$263 ; 2000$ ), and the offer at the meeting to supply nevirapine free for a limited period (see page 223).

There is no doubt that the urgent need for access to antiretrovirals in developing countries is at last receiving the full attention of the pharmaceutical industry. The South African government has shown little enthusiasm for the offers, but the Durban meeting will help to create international pressure on all parties to reach a compromise that will release the necessary drugs to Africans at affordable cost.

In his closing address to the conference, Nelson Mandela, the former South African president, took an unequivocal stand on the need for his country to implement a programme to reduce mother-tochild-transmission of the virus. His speech was described by conference chairman Jerry Coovadia as a "watershed" in the fractious debate over AIDS that has raged in South Africa since last October.

It is to be hoped that Mandela's words will prompt his successor to reconsider his stand on the aetiology of HIV/AIDS and on antiretroviral drugs. His speech should make it easier for government officials to press for the introduction of treatment programmes for HIV-positive mothers. It will also lift some of the pressure off South Africa's beleaguered physicians and AIDS scientists, who have faced derision and pressure from political leaders over the past nine months. Most importantly, it provides some hope for the tens of millions of Africans who are living with HIV.

\section{SOS (again) at the Department of Energy}

\section{Congress should provide adequate support for facilities operated on behalf of all US scientists.}

t is ironic that, only weeks after politicians so eagerly celebrated the imminent completion of a draft of the human genome sequence, science programmes at the Department of Energy (DoE) should find themselves under pressure again (see page 221).

Ironic, because it was the DoE, with its traditional strength in 'big science', that got the Human Genome Project under way in the first place, in the face of tenacious resistance from the National Institutes of Health (NIH), which later acquired leadership of the project.

The NIH is now enjoying a major build-up of funds that is likely to take its budget above $\$ 20$ billion next year. Growing numbers of its investigators rely on large scientific facilities, such as supercomputers or synchrotron light sources, to conduct their research at the frontiers of molecular biology.

But the NIH doesn't operate any large facilities; they are all maintained by the DoE. It has recently agreed to help equip some of the DoE's synchrotrons, in response to the fact that biologists are among their largest users. But the synchrotrons themselves will continue to rely on the DoE for their operation, maintenance and replacement.

The DoE has many enemies in Washington, but even the most bitter of them expresses no desire to damage the US scientific infrastructure. Sound science policy demands a balance between the support of individual investigators - by the NIH and the National Science Foundation - and the maintenance of major facilities, and their associated research programmes, at DoE laboratories. 